\title{
Career motivation of secondary students in STEM: a cross-cultural study between Korea and Indonesia
}

\author{
Sein Shin ${ }^{1}$ - Arif Rachmatullah ${ }^{2}$ Fenny Roshayanti ${ }^{3}$. \\ Minsu $\mathrm{Ha}^{2} \cdot$ Jun-Ki Lee ${ }^{1}$
}

Received: 6 June 2017/ Accepted: 28 December 2017/Published online: 11 January 2018

(C) The Author(s) 2018. This article is an open access publication

\begin{abstract}
The purpose of this study was to understand the career motivation of secondary students in science, technology, engineering, and mathematics (STEM) by comparing Korean and Indonesian students. Effects of gender and educational level on students' STEM career motivation were also examined. To test for differences, we used Rasch analysis, 3-way ANOVA, correlation analysis, and multiple group path analysis. STEM career motivation was found to be significantly affected by interactions between country, gender, and educational level. Overall, Indonesian students had more STEM career motivation than Korean students. Korean students showed larger gender differences in STEM career motivation than Indonesian students.
\end{abstract}

Résumé. La motivation de carrière en STEM des étudiants.es secondaires: Etude interculturelle entre la Corée et l'Indonésie L'objectif de cette étude était de comprendre les motivations de carrière des étudiants.es secondaires en Science, Technologie, Ingénierie, et Mathématiques (STEM) en comparant les étudiants.es de Corée et d'Indonésie. Les effets du genre et du niveau d'éducation sur la motivation de carrière des étudiants.es en STEM ont aussi été examinés. Pour tester les différences, nous avons utilisé l'analyse de Rasch, l'ANOVA à trois facteurs, l'analyse de corrélations, et l'analyse de pistes causales de groupes multiples. La motivation de carrière en STEM était affectée significativement par les interactions

Jun-Ki Lee

junki@jbnu.ac.kr

1 Division of Science Education, Biology Major, Chonbuk National University, Jeonju, Republic of Korea

2 Division of Science Education, Biology Major, Kangwon National University, Chuncheon, Republic of Korea

3 Department of Biology Education, Faculty of Mathematics, Science and Information Technology Education, University of PGRI Semarang, Semarang, Indonesia 
entre le pays, le genre et le niveau d'éducation. Globalement, les étudiants.es Indonésiens avaient plus de motivation de carrière en STEM que les étudiants.es Coréens. Les étudiants Coréens avaient de plus grandes différences de genre dans la motivation de carrière en STEM que les étudiants.es Indonésiens.

Zusammenfassung. Die Motivation von Sekundarschülern/innen, STEMFächer zu studieren: Ein Vergleich zwischen Korea und Indonesien Ziel dieser Studie war es, die Motivation von Sekundarschülern/innen, Naturwissenschaften, Technik, Ingenieurwissenschaften und Mathematik (STEM) zu studieren, zu untersuchen. Dabei wurden Schüler/innen aus Korea und Indonesien miteinander verglichen. Der Einfluss des Geschlechts und des Bildungsniveaus auf die Motivation, ein STEM-Fach zu studieren, wurde ebenfalls untersucht. Die Unterschiede haben wir anhand von Rasch-Analysen, dreifaktoriellen ANOVA, Korrelationsanalysen und Mehrgruppen-Pfadanalysen untersucht. Es hat sich gezeigt, dass die Motivation, STEM-Fächer zu studieren, signifikant von der Wechselwirkung zwischen Land, Geschlecht und Bildungsniveau beeinflusst wird. Insgesamt hatten die indonesischen Schüler/innen eine höhere Motivation, STEM-Fächer zu studieren, als die koreanischen Schüler/innen. Bei den koreanischen Schüler/innen waren die Geschlechtsunterschiede größere als bei den indonesischen Schüler/innen.

Resumen. Motivación de los estudiantes de secundaria para la carrera en STEM: Estudio transcultural entre Corea e Indonesia. El propósito de este estudio fue entender la motivación de los estudiantes de secundaria para la carrera en Ciencias, Tecnología, Ingeniería y Matemáticas (STEM) comparando estudiantes de Corea e Indonesia. También se examinaron los efectos de género y nivel educativo sobre la motivación de los estudiantes para la carrera en STEM. Para probar las diferencias se usó el análisis Rasch, el 3 vias ANOVA, el análisis correlacional y el análisis de ruta en grupo múltiple. La motivación para la carrera en STEM se encontró significativamente afectada por las interacciones entre país, género y nivel educativo. En general, los estudiantes indonesios tenían más motivación para la carrera en STEM que los estudiantes coreanos. Los estudiantes coreanos mostraron mayores diferencias de género en las motivaciones para la carrera en STEM que los estudiantes indonesios.

Keywords Career motivation · Cross-cultural study $\cdot$ STEM

\section{Introduction}

Achievements in science, technology, engineering, and mathematics (STEM) are closely related to the competitiveness and creative innovation of the country. Therefore, many countries are investing heavily in STEM fields, and STEM has been growing rapidly in recent decades. Demand for workers with STEM-related capabilities is also growing globally. However, although many countries have been heavily investing in STEM fields, the lack of a STEM workforce has been 
continuously reported around the world (Marginson, Tytler, Freeman, \& Roberts, 2013; Wang, 2013).

Because secondary education is a critical period for individual career development, as career exploration and identity building arise mainly in this period (Super, 1980), many researchers have paid attention to secondary students' motivation to participate in STEM careers in order to solve the shortage of a STEM workforce. Therefore, many studies of STEM education have emphasized the role of secondary students' interest and motivation to participate in STEM majors and careers (Nugent et al., 2015; Oh, Jia, Lorentson, \& LaBanca, 2013; Riegle-Crumb, Moore, \& Ramos-Wada, 2011). In particular, Wang (2013) examined students' intentions to select STEM majors in college and found their intentions to be affected by early learning experiences and motivational attributes, such as self-efficacy in math during 12th grade. In this regard, many STEM education researchers have tried to improve secondary students' STEM career motivation (Hamilton, Malin, \& Hackmann, 2015; Schneider, Judy, \& Mazuca, 2012). However, students' motivation for STEM careers has been mainly studied in developed Western countries. Although a few studies have focused on Asian students, most of these use AsianAmerican samples (Hamilton et al., 2015; Mau, 2016; Palmer, Maramba, \& Dancy, 2011). In addition, although STEM fields are expanding globally with a shortage of STEM workforce being increasingly reported in many countries, it is currently unclear whether students' stance and perspective on a STEM career differs according to the socio-economic context of their country.

This study focused on secondary students' STEM career motivation in two Asian countries: Indonesia and Korea. These countries were chosen based on their backgrounds of science literacy achievement, which is considered to be a prominent factor of STEM education and career choice (Mullis, Martin, Foy, \& Hooper, 2016; OECD, 2016). Indonesian students have been known for more than a decade to be low achievers in the Program for International Student Assessment (PISA) and Trends in International Mathematics and Science Study (TIMSS), whereas Korean students consistently score at the top level. Moreover, there are many stereotypes about Asians, for example that Koreans, Chinese, and Japanese have advanced STEM-related knowledge and abilities (Marton, Watkins, \& Tang, 1997). In this study, we attempt to reduce stereotyping by showing that the characteristics of "Asians" are diverse. Importantly, the two samples represent countries in the Asian subregion (i.e., Southeast Asia and East Asia) with different socio-economic status (i.e., a low-middle-income group and a high-income group) based on World Bank classification (Fantom \& Serajuddin, 2016). Hence, we attempt to compare secondary students' STEM career motivation between Korea and Indonesia for a better understanding of students' motivation toward STEM in Asian countries.

Many previous studies in developed Western countries facing a STEM shortage have examined the effects of students' gender and educational level or age on interest in and motivation for STEM careers. In terms of gender, previous studies have addressed female students' motivation for STEM careers, since females are generally underrepresented in STEM fields (Halpern et al., 2007; Wang \& Degol, 2017). Especially, it has been found that female students have significantly worse self-concepts or less interest in learning STEM subjects than male students 
(Lofgran, Smith, \& Whiting, 2015; Meece, Glienke, \& Burg, 2006). In addition, previous studies have pointed out that students' attitude and motivation towards STEM-related subjects and careers are associated with their educational level, especially during transitions, such as from middle school to high school (Barmby, Kind, \& Jones, 2008; Lofgran et al., 2015; Sorge, 2007). However, little is known about the differential effects of gender and education level on students' STEM career motivation in developing versus developed countries in Asia. Thus, students' gender and educational level were considered to be important group variables in this study.

Over the last few decades, international comparative studies, such as PISA, have helped researchers and educators understand how students' cognitive and affective learning achievements can differ according to country, academic year, and gender (Chiu \& Duit, 2011). They have also helped STEM education researchers gain a broader understanding of the effect of socio-cultural context on STEM achievement. Results from various international comparative studies have provided important information for educational researchers around the world to grasp the global educational situation and implications of STEM education in their own countries. Thus, findings from this study are also expected to provide insight on students' career motivation in Korea, Indonesia, and other Asian countries with similar backgrounds.

\section{Korean and Indonesian cultural background related to STEM career education}

To understand secondary students' STEM career motivation, each country's characteristics of STEM field and its socio-cultural background need to be considered together. Therefore, we will first briefly review backgrounds related to STEM fields and STEM education in Korea and Indonesia.

\section{STEM fields in Korea and Indonesia}

According to the science, technology, and industry scoreboard reported by the Organization for Economic Cooperation and Development (OECD), Korea and Indonesia have different profiles in terms of a STEM workforce (OECD, 2015). Among 41 participating countries in the science, technology, and industry scoreboard 2015, Korea has the highest percentage of graduates (32\%) from natural sciences and engineering among college graduates. Its ratio of research and development (R\&D) to gross domestic product (GDP) in 2013 was the second highest in the OECD. In addition, the proportion of R\&D researchers in Korea was $12.8 \%$ per employed population in 2013, the 6th highest among participating countries (OECD, 2015). Given these indexes, it seems that STEM in Korea is expanding rapidly. However, according to a UNESCO report on the rate of women's participation in STEM, gender equality has not been achieved in Korea yet. UNESCO has reported that only $29 \%$ of Natural science and engineering graduates are female, and $17 \%$ of R\&D researchers are female in Korea (UNESCO, 2015). 
The proportion of graduates with natural sciences and engineering majors was $24 \%$ in Indonesia, which was lower than that in Korea. However, half (48\%) of these graduates are female, which was the highest among OECD countries (OECD, 2015). In addition, $31 \%$ of $R \& D$ researchers in Indonesia were female, a much higher figure than that for Korea (UNESCO, 2015). However, Indonesia is also known to be short of skilled STEM workers to meet the demand. The proportion of researchers per thousand employed population in Indonesia was only $0.2 \%$ (OECD, 2015). Thus, the need for STEM education to train STEM experts with scientific competencies has been emphasized in Indonesia (World Bank, 2010). These distinctive features of STEM fields that the two countries are facing would be closely related to the characteristics of secondary students' career motivation toward STEM. However, to date, very limited research has been done on secondary students' STEM career motivation in the two countries.

\section{Korean socio-cultural background related to STEM education}

According to several international reports, such as PISA and TIMSS, that have assessed math and science achievement, Korea has placed in the highest rank globally with countries such as Singapore, Japan, and Taiwan. For instance, in PISA 2015, Korea's 8th-grade students' science achievement was ranked 5th among OECD countries (OECD, 2016). Korean students' science achievement was also ranked 4th among participating countries in TIMSS 2015 (Mullis et al., 2016). In contrast, Korean students have shown very low levels of motivation for science and math learning. For instance, in TIMSS 2015, Korean students' confidence, interest, and value perception in science and math were much lower than that of students from other participating countries (Mullis et al., 2016). This paradoxical phenomenon has so far been studied mainly in terms of cultural context, such as Confucianism and collectivism, which are common value systems in East Asia. One reason for such a paradoxical situation is that a Confucian culture highly emphasizes the role of education in society; parents have a passion for their children's education in collectivist cultures (Lee, Rojewski, \& Hill, 2013; Shin, Ha, \& Lee, 2017). In addition, a "big fish little pond effect" model, in which students who have shown high average achievement tend to have a low self-concept because of social comparison or pressure, has been suggested as a plausible reason for East Asian students' low self-concept for math and science (Liou, 2014; Marsh et al., 2008). These contextual factors can lead to higher math and science achievement. However, they might also hinder the formation of students' academic motivation.

In addition to Korean students' low academic motivation toward science, the number of students avoiding STEM is increasing. This has become another social issue in Korean STEM fields (Jon \& Chung, 2013). One major cultural context behind this phenomenon is that many Koreans tend to value job stability. Although Korean has successfully overcome the 1997 Asian financial crisis, which resulted in many job losses, Koreans since then have valued job stability more and prefer careers that provide stability, such as government officials, teachers, or doctors (Koo, 2000). With this background, it is becoming a social issue in Korea that a large proportion of students in STEM majors, especially those with high 
achievements in science or math, tend to move away from STEM and to become civil servants or medical doctors instead (Jon \& Chung, 2013).

In order to improve students' academic and career motivation toward STEM, the Korean government has initiated national investment policies for STEM fields. For example, Brain Korea 21 (BK21) is a national project that supports graduate students in science and technology. In addition, Quotas in college admissions for STEM major in STEM fields has been rapidly increasing for decades because of the Korean government's legislation to meet industrial demands (Jon \& Chung, 2013). However, most projects have been set up only for tertiary education and graduate scholars in STEM fields of universities. Secondary education for STEM careers has mainly focused on systems for talented or gifted students in math and science. For general secondary students, STEM has received relatively little attention.

\section{Indonesian socio-cultural background related to STEM education}

Unlike the findings from PISA and TIMSS on Korean students' achievement, Indonesian students' achievements in math and science have hovered around the bottom tenth among OCED participating countries. In PISA 2015, Indonesian students' achievements in science and math were ranked 64th and 65th out of 72 countries (OECD, 2016). In addition, TIMSS 2015 reported that Indonesian 4th graders were ranked 44th out of 47 participating countries in science and of 49 countries in math (Mullis et al., 2016). These findings on cognitive achievement were different from PISA and TIMSS findings on affective domains. Based on TIMSS 2015, Indonesian 4th graders identified as liking very much to learn science and math, consistent with PISA 2015 findings (Mullis et al., 2016; OECD, 2016). The positive attitude of Indonesian students towards learning science and math, the core of STEM education, could result from the socio-economics of that country. As a developing country, Indonesia needs development in the field of STEM to establish more stable financial and social conditions. Thus, in the last decade, the Indonesian government has attempted to provide as many workplaces in the fields of STEM as possible (Chen, 2009). The Indonesian government has even increased financial rewards for those working in STEM fields. Such efforts might have stimulated Indonesian students to have more interest in learning science and math. In the fields of technology and engineering, an increasing number of established vocational schools (equal to high school) contribute to STEM education in Indonesia (Indonesia Ministry of National Education, 2006). The increasing number of vocational schools might reflect better work prospects of STEM careers in Indonesia.

According to a report by Newhouse and Suryadarma (2011), the Indonesian vocational-school program is one of the most successful vocational school programs. Indonesian vocational schools have gained much popularity and supports from several social factors. However, the most important support is from parents (Misbah, Gulikers, Maulana, \& Mulder, 2015; Newhouse \& Suryadarma, 2011). Most parents believe that if their children are enrolled in vocational schools, they will gain more advanced skills and thus have an advantage over those who enroll in general high schools (Misbah et al., 2015). Perhaps because of this, the number of 
vocational school students in Indonesia exceeded the number of general high-school students in 2015 (JPPN, 2015). In response, the Ministry of Education and Culture in Indonesia has compiled a new curriculum for general high schools, published in 2013 and revised in 2016, that stated that teaching and learning activities in general high schools should better address STEM topics (Mendikbud, 2016).

\section{STEM career motivation}

Social cognitive career theory (SCCT) was used as the theoretical framework in this study to understand students' motivation to have a STEM career. SCCT posits that career development is influenced by continuous interactions between personal cognitive factors (e.g., self-efficacy) and contextual factors (e.g., parental support; Lent, Brown, \& Hackett, 1994). In this study, seven constructs of STEM career motivation suggested by Shin, Ha, and Lee (2016) within the SCCT framework were included. Lent et al. (1994) proposed that support from the external environment plays a role as a critical regulator in the process of individual career development. We focused on contextual factors, educational experience and parental support in this study. According to Wang (2013), high-school students' exposure to science and math courses is a significant predictor of their intention to select STEM as a major. A regular STEM class in formal education could be used as a pathway for students to obtain information about STEM careers through teachers or textbooks. Thus, this study focused on students' educational experience about STEM careers in regular STEM classes as a contextual factor.

Parental support, especially parents' emotional support, plays a positive role in adolescents' career development (Lent, Brown, \& Hackett, 2000; Simpkins, DavisKean, \& Eccles, 2006). Particularly, in a collectivist culture, Asian students' career development is more influenced by parental support and involvement than is that of western students (Leong, 1993). Thus, parental support was noted as a contextual factor in this study to understand STEM career development of students in both countries.

In terms of personal factors, perceived career values, academic self-efficacy, career self-efficacy, career interest, and goal setting were the focus of this study. Career values are internal or external rewards or results that one expects to gain through the chosen career. Previous research has shown that perceptions of value are closely related to career development and decisions (Fouad et al., 2008). For example, some researchers have found that women tend not to prefer STEM careers, except in bio-medicine, because they value altruistic behavior or interpersonal relationships more than men (Diekman, Clark, Johnston, Brown, \& Steinberg, 2011). In this regard, students who perceive more positive values of a STEM career are more likely to be motivated to pursue a STEM career.

Another noted personal factor in this study is self-efficacy, a crucial cognitive factor in SCCT (Lent et al., 1994). Self-efficacy refers to one's belief about one's abilities to carry out a particular task (Bandura, 1977). In this study, we distinguished academic self-efficacy on STEM subjects and career self-efficacy on a future STEM career. According to a previous study, academic self-efficacy on STEM is closely related to interest in learning STEM and a STEM career path 
(Wang, 2013). In particular, it has been reported that the underrepresentation of women in STEM is closely related to their low self-efficacy in math and science subjects (Hackett \& Betz, 1989). In addition, Hackett \& Bryars (1996) found that students' belief in whether they have appropriate capacities for a STEM career is an important factor in career development. Thus, career self-efficacy, belief in oneself related to career decisions, goals, and career behavior, was also considered to be a cognitive factor of career motivation in this study.

Interest and goals are crucial factors for human motivation (Renninger \& Su, 2012; Schunk \& Usher, 2012). Career interest refers to a positive attitude toward activities in a particular career. According to SCCT, formation of personal interest in a career is affected by positive self-efficacy and outcome expectations. It can directly develop into career motivation with a specific goal by interacting with surrounding contextual factors (Lent et al., 1994). Career goals refer to an individual's intentions to participate in particular activities or obtain desired results in future careers (Lent et al., 1994). The specific goal is a key factor in building motivation that organizes or maintains some behaviors (Schunk \& Usher, 2012). In particular, Holland (1997) has claimed that a person's vocational identity depends on clear career goal setting, and that ambiguity of career identity is closely related to maladaptive career development. In this regard, students with high STEM career motivation would have clearly set their career goals as STEM fields. Thus, individual interests and goals related to STEM were considered as constructs of career motivation.

\section{Effect of gender and education level on STEM career motivation}

As we mentioned, gender is one of the most studied factors related to STEM career since women in many countries are traditionally underrepresented in STEM fields. Previous study has suggested that female students' low interest and confidence in math and science, beginning in childhood, are reasons for their underrepresentation in STEM (Meece et al., 2006). This inequality of gender is complexly intertwined with various factors such as gender stereotype and cultural context for STEMrelated occupations (Good, Aronson, \& Harder, 2007). Therefore, gender should be taken into account to understand differences in motivations between two different countries with different cultural contexts.

Another factor considered in this study was educational level (middle versus high school). As mentioned earlier, previous studies have reported that students' motivation to learn science and have STEM careers declines with time. (Barmby et al., 2008; Lofgran et al., 2015). In particular, as each type of school has differences in curriculum and educational environment, students' career development related to STEM would differ by school type. In this regard, STEM career motivation might differ by educational level. Thus, based on previous research, we considered gender and educational level to be individual variables when comparing STEM career motivation between students from the two countries. 


\section{Goals for the present study}

The overarching purpose of the present study was to understand secondary students' career motivation toward STEM by comparing that of Korean and Indonesian students with examination of the effect of gender and educational level. To achieve this purpose the current study adopted a descriptive cross-sectional approach. First we examined the differences of STEM career motivation in the countries by 3-way ANOVA. In addition, we examined how gender and education level affected career motivation. Second, the difference in relationships between the components of STEM career motivation by country was examined by Pearson correlation analysis and multiple group path analysis based on structural equation modeling (SEM).

Before comparing students' STEM career motivation between the countries, the validity of the instrument for measuring STEM career motivation was examined using Rasch analysis based on item response theory (IRT). In particular, generalizability validity associated with unbiased measurement was examined for valid comparison of data from heterogeneous groups (Messick, 1995), because item responses might appear differently for respondents with different cultural contexts, possibly leading to biased measurements and interpretations.

\section{Methods}

\section{Participants}

The total number of participants for this study was 2171 Indonesian and Korean students. These samples consisted of 8 th and 10th graders as representative of middle school and high school. Students in the 2 nd year of middle school and 1st year of high school were purposely selected as research subjects because of their age (about 15 years old). As stated by OECD (2016) in their international assessment program PISA, the age of 15 years is the borderline between childhood and adulthood. It is a crucial period for students to engage in real-life decisions about their future careers.

Of these 2171 students, 952 (44\%) were Indonesian and $1219(56 \%)$ were Korean. Of the 952 Indonesian students, 413 (43\%) were male and 539 (57\%) were female. These Indonesian students included 365 (38\%) middle-school students and $587(62 \%)$ high-school students, all of whom were enrolled in public schools. There are two types of public school in Indonesia: general and Islamic-based. We collected samples from both types. In the Korean samples, there were 697 (57\%) male and $522(43 \%)$ female students. The Korean sample was equally distributed by educational level, including 604 (50\%) middle-school students and $615(50 \%)$ high-school students. 


\section{Instrument}

The STEM career motivation (STEM-CM) instrument developed by Shin et al. (2016) was used to assess STEM career motivation. It has been previously validated on Korean samples by a combination of IRT-Rasch and Classical Test Theory (CTT; Shin et al., 2016). The STEM-CM measures seven subcomponents of STEM career motivation: educational experience, career value, academic self-efficacy, career self-efficacy, career interest, parental support, and goal setting.

This instrument includes 32 items measured on a 5-point Likert scale. Of these, three measure educational experience related to STEM careers such as, "I learned about STEM careers through science, mathematics, and technology subject teachers"; nine measure values about STEM careers such as, "A STEM career has many opportunities for self-realization"; five measure academic self-efficacy such as, "I am confident that I can understand subjects such as science, mathematics, and technology well"; four items were for measuring career selfefficacy such as, "I believe I can adapt to a STEM career well"; three measure career interest such as, "I am interested in a STEM career"; four measure parental support such as, "My parents understand my decision on a STEM career"; and four measure goal setting such as, "I have a clear career goal related to STEM".

\section{Examination of validity and reliability of the instrument}

To establish the validity and reliability of the instrument for measuring students' STEM career motivation, four aspects of item responses on the STEM-CM instrument were examined: dimensionality, item fit, reliability, and differential item functioning (DIF). Because of the issue of sample independence in Rasch (Boone \& Scantlebury, 2006), it was not necessary to test the validity of the STEM-CM instrument for Indonesian data. However, dimensionality of the instrument was not psychometrically examined in the study of Shin et al. (2016). Therefore, we tested the dimensionality of the STEM-CM instrument using Rasch analysis in data from both countries to determine whether the data better supported a multi-dimensional instrument or a unidimensional interpretation of the instruments. A seven-dimension model and a one-dimension model were compared in terms of final deviance, Akaike Information Criterion (AIC), and $\chi^{2}$. A standard from Bond and Fox (2015) was used to decide on the best model based on these three benchmarks (lower final deviance, lower AIC, and higher $\chi^{2}$ than the comparator model).

For reliability, both IRT-based Rasch analysis and CTT were used. Item and person reliabilities were obtained from the Rasch analysis. Person reliability was rated as the probability of a student's consistency in response for every item scaled by its difficulty (Bell, 1982). Item reliability refers to how much the contribution of every item in explaining the variance of total score (Boone, Staver, \& Yale, 2014). Item and person reliability coefficients can be interpreted using the same as the benchmarks of internal consistency as in CTT methods. One such benchmark is Cronbach's alpha. Thus, the benchmark of internal consistency suggested by DeVellis (2003) was used as standard in this study to interpret item and person reliability as well as Cronbach's alpha. DeVellis (2003) has suggested that a 
coefficient below .6 is "unacceptable", .60-.69 is "undesirable to minimally acceptable", .70-.80 is respectable, and above .80 is "very good" for an instrument.

DIF is defined as a statistical test of the measurement bias of items. The occurrence of bias means that a particular item can be easily answered correctly by a specific group in the sample. Thus, group comparison cannot be performed when bias is significant (Boone et al., 2014). It is related to the generality of the instrument. This analysis could be done by Rasch analysis. The benchmark of DIF difference $>.64$, as suggested by Boone et al. (2014), was used in this study to define significant and meaningful bias.

\section{Statistical analyses}

Raw survey responses were ordinal, a problem for parametric analyses. Thus, the Rasch method was used to convert ordinal data to interval data. Rasch analyses were run eight times, once for overall career motivation data and once for every dimension in the STEM-CM instrument. Thus, eight person ability values for every student were obtained and used for further statistical analysis. Rasch analyses were run in WINSTEP version 3.92.1. To find the number of dimensions, multidimensional analyses were run in ACER Conquest version 4.5.0.

The effects of country, gender, and educational level on STEM career motivation were examined by 3-way ANOVA. To examine the difference of relationships between components of STEM-CM by country, we used Pearson correlation analysis and multiple group path analysis based on structural equation modeling (SEM). For multiple group analysis, we hypothesized a model based on SCCT and examined the model fit in the full sample. We compared the fitness of unconstrained and constrained models that parameters, such as weight, covariance, and residual in each path model for both country group are assumed to be equal.

Because $\chi^{2}$ is almost always significant with a large sample, model fit and significant model difference was examined based on fit indices such as CFI and RMSEA (Cheung \& Rensvold, 2002). When the fitness of a nested constraint model is worse than that of an unconstrained model, the equality constraint of the parameter can be rejected. Therefore differences of fit indices between the models were examined. SPSS 22 was used for ANOVA and correlation analysis and AMOS 21.0 for path analysis.

\section{Results}

\section{Validity and reliability of the measurement instrument}

The results of the multi-dimensional analysis are shown in Table 1. Better fit was obtained when seven dimensions in both countries data were considered. Although the $\chi^{2}$ values of the seven-dimension model were higher than comparator model whereby should be lower than the comparator model for indicating a better model; however two others aspects which are AIC and final deviance met the benchmark. Treating the inventory as seven dimensions was also suggested by item- 
fit values, which were in the range of the benchmark-based mean-square (MNSQ). The benchmark of item-fit suggested by Wright, Linacre, Gustafson, and Martin-Löf (1994) was used to assess the quality of items. An item can be called misfitting when its MNSQ values are outside the range of 0.70-1.40. As shown in Table 2, the seven-dimensional model had the best fitting items. In contrast, four misfitting items one overfitting item and three underfitting were found when the STEM-CM instrument was treated as unidimensional.

Based on the results shown in Table 2, both item and person reliability, as well as Cronbach's alpha coefficients were above .80; the lowest for person reliability was .81 and for item reliability and alpha was .85 . Thus, we concluded that both STEM$\mathrm{CM}$ items and responses were reliable. To assess item-response bias, data were divided into eight different groups based on country, gender, and educational level,

Table 1 Dimensionality analysis results

\begin{tabular}{llllrlr}
\hline Country & Number of dimension & Final Deviance & AIC & $\chi^{2}$ & df & $p$ value \\
\hline Indonesia & One-dimension & 69768.73 & 70026.73 & 467.13 & 31 & $<.001$ \\
& Seven-dimension & 66856.92 & 67168.92 & 1675.51 & 25 & $<.001$ \\
\multirow{2}{*}{ Korea } & One-dimension & 87689.60 & 87947.60 & 1727.48 & 31 & $<.001$ \\
& Seven-dimension & 76365.11 & 76677.11 & 755.18 & 25 & $<.001$ \\
\multirow{2}{*}{ Both countries } & One-dimension & 160339.17 & 160597.17 & 1349.46 & 31 & $<.001$ \\
& Seven-dimension & 147046.21 & 147358.21 & 835.41 & 25 & $<.001$ \\
\hline
\end{tabular}

Table 2 Validity and reliability of instrument for STEM career motivation

\begin{tabular}{|c|c|c|c|c|c|c|}
\hline \multirow[t]{2}{*}{ Components } & & \multicolumn{2}{|l|}{ Item-fits } & \multirow{2}{*}{$\begin{array}{l}\text { Person } \\
\text { reliability }\end{array}$} & \multirow{2}{*}{$\begin{array}{l}\text { Item } \\
\text { reliability }\end{array}$} & \multirow{2}{*}{$\begin{array}{l}\text { Cronbach's } \\
\text { alpha }\end{array}$} \\
\hline & & $\begin{array}{l}\text { Infit } \\
\text { MNSQ }\end{array}$ & $\begin{array}{l}\text { Outfit } \\
\text { MNSQ }\end{array}$ & & & \\
\hline \multirow{2}{*}{$\begin{array}{l}\text { Career motivation in } \\
\text { STEM (All) }\end{array}$} & Lowest & 0.67 & 0.67 & \multirow[t]{2}{*}{.94} & \multirow[t]{2}{*}{.99} & \multirow[t]{2}{*}{.96} \\
\hline & Highest & 1.52 & 1.58 & & & \\
\hline \multirow[t]{2}{*}{ Educational experience } & Lowest & 0.83 & 0.79 & \multirow[t]{2}{*}{.83} & \multirow[t]{2}{*}{.85} & \multirow[t]{2}{*}{.86} \\
\hline & Highest & 1.19 & 1.13 & & & \\
\hline \multirow[t]{2}{*}{ Career value } & Lowest & 0.83 & 0.82 & \multirow[t]{2}{*}{.81} & \multirow[t]{2}{*}{.98} & \multirow[t]{2}{*}{.85} \\
\hline & Highest & 1.17 & 1.22 & & & \\
\hline \multirow[t]{2}{*}{ Academic self-efficacy } & Lowest & 0.92 & 0.89 & \multirow[t]{2}{*}{.89} & \multirow[t]{2}{*}{.94} & \multirow[t]{2}{*}{.92} \\
\hline & Highest & 1.02 & 1.00 & & & \\
\hline \multirow[t]{2}{*}{ Career self-efficacy } & Lowest & 0.89 & 0.85 & \multirow[t]{2}{*}{.88} & \multirow[t]{2}{*}{.95} & \multirow[t]{2}{*}{.91} \\
\hline & Highest & 1.20 & 1.15 & & & \\
\hline \multirow[t]{2}{*}{ Career interest } & Lowest & 0.85 & 0.78 & \multirow[t]{2}{*}{.88} & \multirow[t]{2}{*}{.89} & \multirow[t]{2}{*}{.91} \\
\hline & Highest & 1.09 & 1.01 & & & \\
\hline \multirow[t]{2}{*}{ Parental support } & Lowest & 0.81 & 0.74 & \multirow[t]{2}{*}{.89} & \multirow[t]{2}{*}{1.00} & \multirow[t]{2}{*}{.94} \\
\hline & Highest & 1.08 & 0.98 & & & \\
\hline \multirow[t]{2}{*}{ Goal setting } & Lowest & 0.91 & 0.90 & \multirow[t]{2}{*}{.89} & \multirow[t]{2}{*}{.89} & \multirow[t]{2}{*}{.92} \\
\hline & Highest & 1.04 & 1.01 & & & \\
\hline
\end{tabular}


e.g., Indonesian male middle-school students, Korean female high-school students, etc. A total of 2304 DIF contrast values were obtained. Among these, 1172 were positive, but $12 \%$ were outside the benchmark range. However, these $12 \%$ were still acceptable as being without highly meaningful bias. As stated by Crane et al. (2007), the occurrence of bias could be ignored when the context stated in the item does not point to one particular group. Thus, we believe these values can be used for further analysis.

\section{Effect of country, gender, and educational level on STEM career motivation}

After examining the validity and reliability of the STEM-CM, we used three-way ANOVA to examine the effect of country, gender, and educational level on each motivational construct. As shown in Table 3, country had significant effects on learning experience, $F(1,2163)=31.90, p<.01, \eta_{p}^{2}=.02$, academic selfefficacy, $F(1,2163)=211.39, p<.01, \eta_{p}^{2}=.09$, career self-efficacy, $F \quad(1$, $2163)=81.19, \quad p<.01, \eta_{p}^{2}=.04$, and goal setting, $F(1,2163)=123.43$, $p<.01, \eta_{p}^{2}=.05$. According to Cohen (1969), benchmarks for partial eta-squared $\left(\eta_{p}^{2}\right)$ are .01 (small), .06 (medium), and .14 (large). Given these benchmarks of effect size, country had a small effect on learning experience, career self-efficacy, and goal setting. It had a medium effect on academic self-efficacy. Gender and educational level also had significant effects on some constructs, but the effects were very small.

Interestingly, interaction effects between country and gender and between country and educational level were all significant $(p<.05)$. The effect size of the interaction between country and educational level was small for six constructs: learning experience, $F(1,2163)=81.66, p<.01, \eta_{p}^{2}=.04$, parental support, $F(1$, $2163)=101.82, p<.01, \eta_{p}^{2}=.05$, academic self-efficacy, $F(1,2163)=38.92$, $p<.01, \eta_{p}^{2}=.02$, career self-efficacy, $F(1,2163)=58.21, p<.01, \eta_{p}^{2}=.03$, career interest, $F(1,2163)=87.07, p<.01, \eta_{p}^{2}=.04$, and goal setting, $F(1$, $2163)=105.98, p<.01, \eta_{p}^{2}=.05$. The interaction effect between country and gender also had a small effect on academic self-efficacy, $F(1,2163)=36.74$, $p<.01, \eta_{p}^{2}=.02$, and career interest, $F(1,2163)=34.04, p<.01, \eta_{p}^{2}=.02$.

\section{Comparison of STEM career motivation}

Levels of person ability by country, gender, and educational level are shown in Figure 1. Each construct is described in detail below.

\section{Overall STEM career motivation}

The average of person ability on overall STEM career motivation is shown in Figure 1a and Table 4. For males, Indonesian middle-school students obtained lower average values than Korean middle-school students. However, Indonesian high-school students had higher motivation than Korean high-school students. For females, both Indonesian middle-school students and high-school students had higher averages than Korean middle-school students and high-school students. 


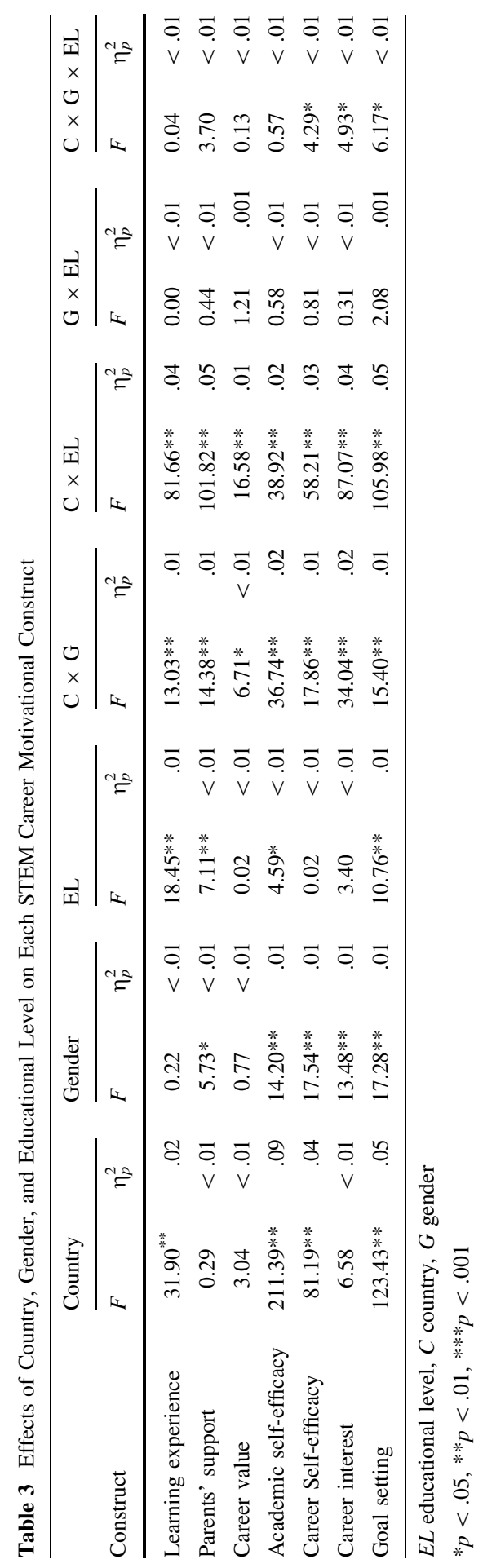




\section{Educational experience}

The results of STEM educational experience are shown in Figure 1b and Table 4. Among males, Indonesian middle-school students had lower averages in STEM educational experience than Korean middle-school students. In contrast, Indonesian high-school students had a higher average than the Koreans. For females, Indonesian and Korean middle-school students had relatively similar STEM education experience. However, female Indonesian high-school students had much higher STEM education experience than those from Korea.

\section{Parental support}

Results of comparison in the level of parental support are shown in Figure 1c. Among male students, Indonesian middle-school students had lower parental support than Koreans. For high school, Indonesian students had slightly higher parental support than Korean students. Similar patterns were also found in female samples. Indonesian middle-school students had lower parental support than Koreans, while Indonesian high-school students had higher parental support than those from Korea.

\section{Career value}

Similar results were obtained for overall STEM career motivation in terms of STEM career value. For males, Indonesian middle-school students perceived lower STEM career value than did those from Korea. However, Indonesian high-school students perceived higher average career value than those from Korea. For females, Indonesian and Korean middle schoolers perceived similar average STEM career values. However, for high-school students, Indonesian females perceived higher values than Korean females.

\section{Academic self-efficacy}

Results of academic self-efficacy in STEM are shown in Figure 1e. For males, both Indonesian middle-school and high-school students had higher academic selfefficacy than Korean middle-school and high-school students, although the difference between middle-school students was smaller. For females, Indonesian middle-school and high-school students had higher academic self-efficacy than Korean middle-school and high-school students.

\section{Career self-efficacy}

Results of career self-efficacy in STEM are shown in Figure 1f. For males, Indonesian middle-school students had career self-efficacy relatively similar to that of Korean middle-school students. However, Indonesian high-school students had higher career self-efficacy than Korean high-school students. Among females, Indonesian middle-school and high-school students had higher career self-efficacy 


\section{a}

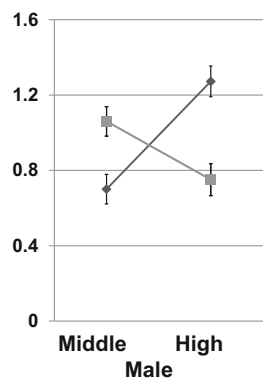

C
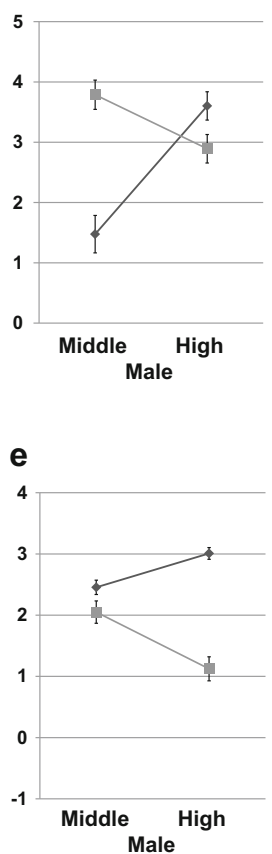

g

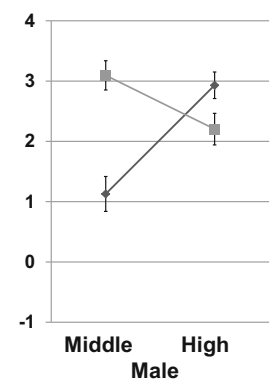

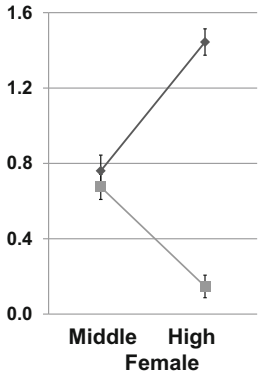

Female

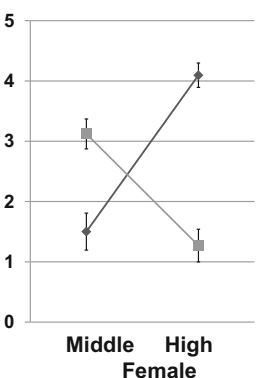

Female

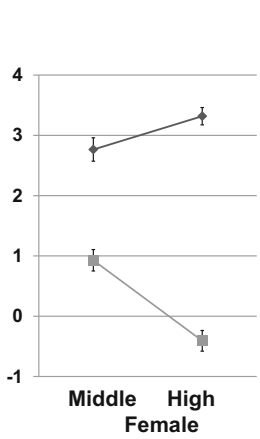

Female

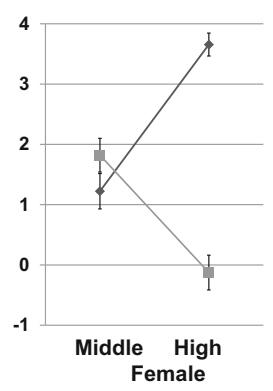

b
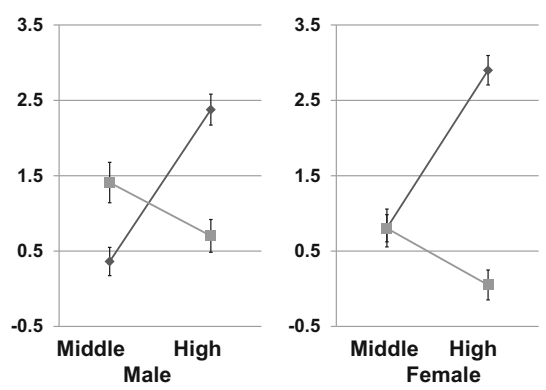

d
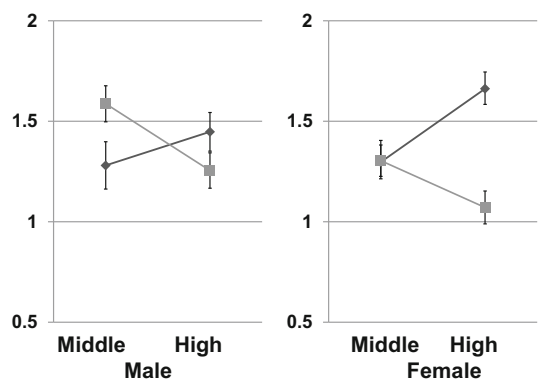

f
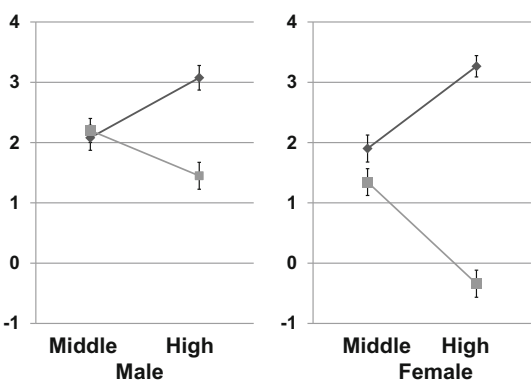

h
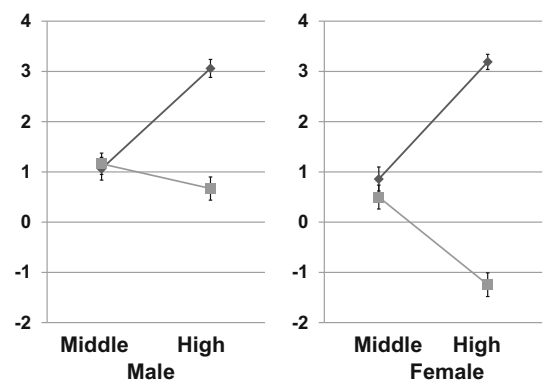
4 Figure 1 a Overall STEM career motivation, b educational experience, c parental support, d career value, e academic self-efficacy, f career self-efficacy, $\mathbf{g}$ STEM career interest, $\mathbf{h}$ goal setting

than Korean middle-school and high-school students, although Indonesian middleschool students had slightly higher career self-efficacy than Koreans.

\section{Career interest}

Results of STEM career interest are shown in Figure 1g. For male students, Indonesian middle-school students had less career interest in STEM than Korean middle-school students. In contrast, Indonesian high-school students had higher career interest in STEM than Korean students. Similarly, female middle-school students in Indonesia had slightly less career interest in STEM than Koreans. However, female high-school students in Indonesia had higher career interest in STEM than Korean students.

\section{Goal setting}

Results of goal setting are shown in Figure 1h. For males, Indonesian and Korean middle-school students had similar average values for goal setting. However, Indonesian high-school students had higher values in goal setting for STEM than Korean students. For females, Indonesian middle-school students had slightly higher level of goal setting Korean. Indonesian high-school students also had higher level of goal setting than Korean students.

Common points of each construct based on the results of three-way ANOVA are summarized below. First, Indonesian students showed higher levels in overall STEM motivation, educational experience, academic self-efficacy, career self-efficacy, and goal setting than Korean students. Second, considering significant interaction effects between country and educational level, middle-school students had higher levels of all STEM career motivation constructs than high-school students in Korea. However, high-school students had higher levels than middle-school students in Indonesia. Third, considering significant interaction effects between country and gender, Korean female students had lower levels of all career motivation constructs than Korean male students. However, gender differences for all STEM career motivation constructs in Indonesia was much less than that in Korea.

\section{Association between constructs of STEM career motivation}

Correlations are summarized in Table 5. All subcomponents of career motivation were significantly correlated $(p<.01)$ with each other. Correlation coefficient $r$ can be interpreted as low $(.30<r<.50)$, medium $(.50<r<.70)$, high $(.70<r<.90)$, and very high $(.90<r<1.00$; Mukaka, 2012). Based on such benchmarks, career self-efficacy and career interest had a high correlation in the sample of Korean male middle-school students $(r=.81)$, Korean female middleschool students $(r=.84)$, and Korean male high-school students $(r=.87)$, Korean female high-school students $(r=.78)$, Indonesian male middle-school students 


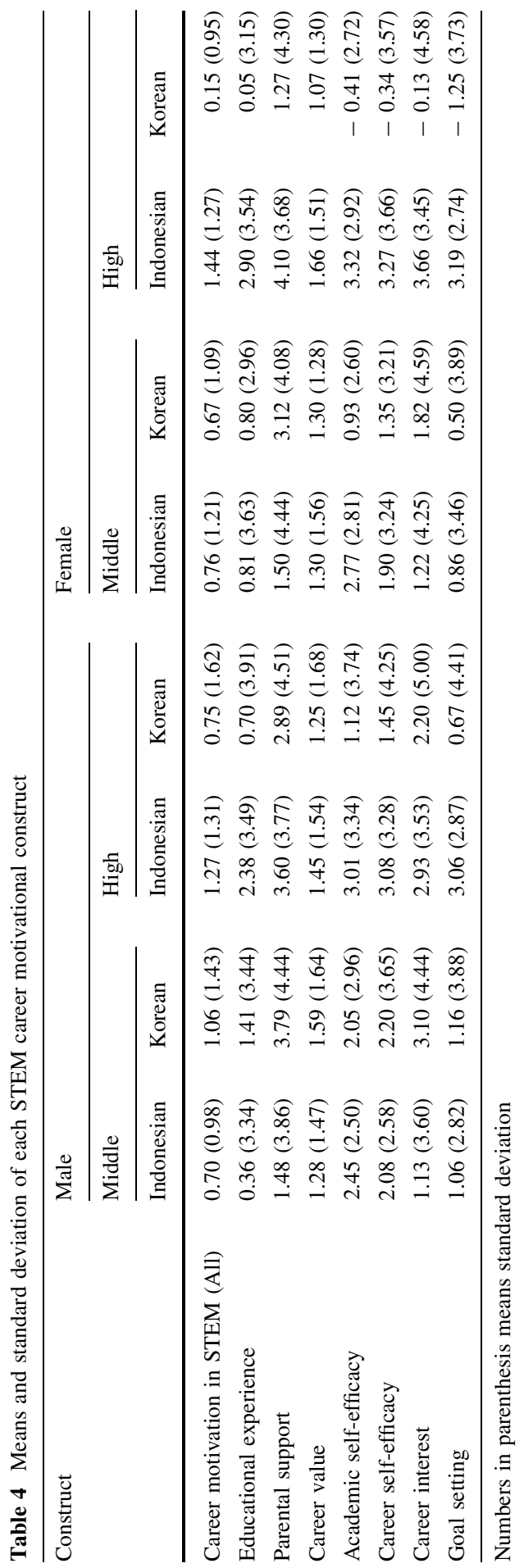


$(r=.70)$, Indonesian female middle-school students $(r=.80)$, and Indonesian male high-school students $(r=.71)$. Career self-efficacy and academic self-efficacy also had a high correlation in Korean students $(r>.70)$; male middle-school students $(r=.73)$, female middle-school students $(r=.70)$, male high-school students $(r=.83)$, and female high-school students $(r=.75)$.

There were some differences in the associations between constructs for each group. In particular, Indonesian students in both genders at both grade levels had relatively higher magnitude associations for most constructs than Korean students. Especially, most correlations between constructs for Indonesian high-school male students were quite high, with at least a medium correlation $(r>.50)$. Another notable feature was that the correlation between parental support and goal setting in all Indonesian groups was higher than .7; male middle-school students $(r=.74)$, female middle-school students $(r=.71)$, male high-school students $(r=.76)$, and female high-school students $(r=.73)$. However, those for Korean students were relatively lower than for Indonesian students.

To understand structural relationships between constructs in STEM career motivation, we hypothesized a path model based on SCCT, as shown in Figure 2, and examined whether a pattern of relationships between constructs was identical or not between our Indonesian and Korean samples. This path model starts from parental support and education as contextual factors and ends with goal setting; academic self-efficacy, career self-efficacy, STEM career value, and career interest are mediators in this pathway. For examining the statistical difference in structural relationship among constructs of STEM career motivation between Korean and Indonesian students, multiple group path analysis with this model was performed.

As shown in Table 6, the result of examining model fit with the full sample showed that our hypothesized model had a satisfactory level of fit (CFI $=.993$, RMSEA $=.084$, SRMR $=.016$ ). However, multiple group analysis results indicated that path coefficients differ by country based on the difference of CFI, RMSEA, and SRMR coefficients between constrained and unconstrained models $(\Delta \mathrm{CFI}=.021, \Delta \mathrm{RMSEA}=-.019, \Delta \mathrm{SRMR}=-.019)$. Increase greater than .01 in CFI is known to indicate a significantly worse model fit (Cheung \& Rensvold, 2002). Thus, our results showed that relations between constructs in STEM career motivation are different between both country groups.

We further compared the path coefficients in each model for Indonesian and Korean students. As shown in Figure 2, Korean students differed from Indonesian on the relation between academic self-efficacy and career interest. While standardized coefficient of this path was significant $(\beta=0.07, p<.05)$ in the model for Indonesian students, it was not significant in the model for Korean $(p=.12)$, which means that academic self-efficacy has no direct effect on career interest in STEM. Given the recommendation that path coefficient above .25 be considered as large relation between variables (Keith, 1993), parental support appears to have considerable influence on career self-efficacy $(\beta=.30)$, career interest $(\beta=.35)$ and goal setting $(\beta=.42)$ for Indonesian students as compared to Korean students. For Korean students, career self-efficacy has a stronger influence on career interest $(\beta=.70)$, and goal setting $(\beta=.42)$ than for Indonesian students. 
Table 5 Pearson Correlation Coefficients

\begin{tabular}{|c|c|c|c|c|c|c|c|c|c|}
\hline \multirow[t]{3}{*}{ Variable 1} & \multirow[t]{3}{*}{ Variable 2} & \multicolumn{4}{|l|}{ Korea } & \multicolumn{4}{|c|}{ Indonesia } \\
\hline & & \multicolumn{2}{|l|}{ Middle } & \multicolumn{2}{|l|}{ High } & \multicolumn{2}{|l|}{ Middle } & \multicolumn{2}{|l|}{ High } \\
\hline & & Male & Female & Male & Female & Male & Female & Male & Female \\
\hline \multirow[t]{6}{*}{$\begin{array}{l}\text { Education } \\
\text { experience }\end{array}$} & $\begin{array}{l}\text { Career } \\
\text { value }\end{array}$ & $0.51 * *$ & $0.36^{* *}$ & $0.48^{* *}$ & $0.24 * *$ & $0.45^{* *}$ & $0.45 * *$ & $0.56^{* * *}$ & $0.57 * *$ \\
\hline & $\begin{array}{l}\text { Academic } \\
\text { self- } \\
\text { efficacy }\end{array}$ & $0.49 * *$ & $0.48 * *$ & $0.57 * *$ & $0.35 * *$ & $0.47 * *$ & $0.42 * *$ & $0.57 * *$ & $0.52 * *$ \\
\hline & $\begin{array}{c}\text { Career self- } \\
\text { efficacy }\end{array}$ & $0.51 * *$ & $0.40 * *$ & $0.58 * *$ & $0.30 * *$ & $0.50 * *$ & $0.61 * *$ & $0.48 * *$ & $0.49 * *$ \\
\hline & $\begin{array}{l}\text { Career } \\
\text { interest }\end{array}$ & $0.46 * *$ & $0.32 * *$ & $0.53^{* *}$ & $0.30 * *$ & $0.50^{* *}$ & $0.62 * *$ & $0.54 * *$ & $0.46^{* *}$ \\
\hline & $\begin{array}{l}\text { Parental } \\
\text { support }\end{array}$ & $0.35 * *$ & $0.26^{* *}$ & $0.42 * *$ & $0.28 * *$ & $0.45^{* *}$ & $0.50 * *$ & $0.57 * *$ & $0.50 * *$ \\
\hline & Goal setting & $0.48 * *$ & $0.20 * *$ & $0.52 * *$ & $0.35 * *$ & $0.47 * *$ & $0.59 * *$ & $0.53 * *$ & $0.48 * *$ \\
\hline \multirow[t]{5}{*}{ Career value } & $\begin{array}{l}\text { Academic } \\
\text { self- } \\
\text { efficacy }\end{array}$ & $0.56 * *$ & $0.42 * *$ & $0.53 * *$ & $0.28 * *$ & $0.56 * *$ & $0.57 * *$ & $0.65 * *$ & $0.60 * *$ \\
\hline & $\begin{array}{c}\text { Career self- } \\
\text { efficacy }\end{array}$ & $0.63 * *$ & $0.37 * *$ & $0.55^{* *}$ & $0.20 * *$ & $0.52 * *$ & $0.54 * *$ & $0.65^{* * *}$ & $0.61 * *$ \\
\hline & $\begin{array}{l}\text { Career } \\
\text { interest }\end{array}$ & $0.60 * *$ & $0.35 * *$ & $0.53 * *$ & $0.22 * *$ & $0.45^{* *}$ & $0.52 * *$ & $0.65 * *$ & $0.60 * *$ \\
\hline & $\begin{array}{l}\text { Parental } \\
\text { support }\end{array}$ & $0.47 * *$ & $0.40 * *$ & $0.42 * *$ & $0.35 * *$ & $0.39 * *$ & $0.40 * *$ & $0.64 * *$ & $0.60 * *$ \\
\hline & Goal setting & $0.54 * *$ & $0.32 * *$ & $0.46^{* *}$ & $0.14 *$ & $0.40 * *$ & $0.51 * *$ & $0.59 * *$ & $0.57 * *$ \\
\hline \multirow{4}{*}{$\begin{array}{l}\text { Academic } \\
\text { self- } \\
\text { efficacy }\end{array}$} & $\begin{array}{c}\text { Career self- } \\
\text { efficacy }\end{array}$ & $0.73 * *$ & $0.70 * *$ & $0.83^{* *}$ & $0.75 * *$ & $0.62 * *$ & $0.67 * *$ & $0.75^{* *}$ & $0.70 * *$ \\
\hline & $\begin{array}{l}\text { Career } \\
\text { interest }\end{array}$ & $0.63 * *$ & $0.65^{* *}$ & $0.71^{* *}$ & $0.62 * *$ & $0.57 * *$ & $0.57 * *$ & $0.63 * *$ & $0.57 * *$ \\
\hline & $\begin{array}{l}\text { Parental } \\
\text { support }\end{array}$ & $0.49 * *$ & $0.37 * *$ & $0.60 * *$ & $0.56 * *$ & $0.41 * *$ & $0.36 * *$ & $0.69 * *$ & $0.65 * *$ \\
\hline & Goal setting & $0.61 * *$ & $0.46^{* * *}$ & $0.69 * *$ & $0.57 * *$ & $0.46^{* *}$ & $0.50 * *$ & $0.70 * *$ & $0.61 * *$ \\
\hline \multirow[t]{3}{*}{$\begin{array}{c}\text { Career self- } \\
\text { efficacy }\end{array}$} & $\begin{array}{l}\text { Career } \\
\text { interest }\end{array}$ & $0.81 * *$ & $0.84 * *$ & $0.87^{* *}$ & $0.78 * *$ & $0.70 * *$ & $0.80 * *$ & $0.71 * *$ & $0.60 * *$ \\
\hline & $\begin{array}{l}\text { Parental } \\
\text { support }\end{array}$ & $0.59 * *$ & $0.46^{* *}$ & $0.65^{* *}$ & $0.65 * *$ & $0.66^{* *}$ & $0.63 * *$ & $0.64 * *$ & $0.62 * *$ \\
\hline & Goal setting & $0.74 * *$ & $0.65^{* *}$ & $0.77 * *$ & $0.75^{* *}$ & $0.66 * *$ & $0.70 * *$ & $0.71 * *$ & $0.69 * *$ \\
\hline \multirow[t]{2}{*}{$\begin{array}{l}\text { Career } \\
\text { interest }\end{array}$} & $\begin{array}{l}\text { Parental } \\
\text { support }\end{array}$ & $0.59 * *$ & $0.46^{* *}$ & $0.64 * *$ & $0.66^{* *}$ & $0.66^{* *}$ & $0.66 * *$ & $0.69 * *$ & $0.63 * *$ \\
\hline & Goal setting & $0.69 * *$ & $0.62 * *$ & $0.76^{* *}$ & $0.70 * *$ & $0.71 * *$ & $0.73 * *$ & $0.71 * *$ & $0.68 * *$ \\
\hline $\begin{array}{l}\text { Parental } \\
\text { support }\end{array}$ & Goal setting & $0.59 * *$ & $0.51 * *$ & $0.66^{* *}$ & $0.59 * *$ & $0.74 * *$ & $0.71 * *$ & $0.76^{* * *}$ & $0.73 * *$ \\
\hline
\end{tabular}


a

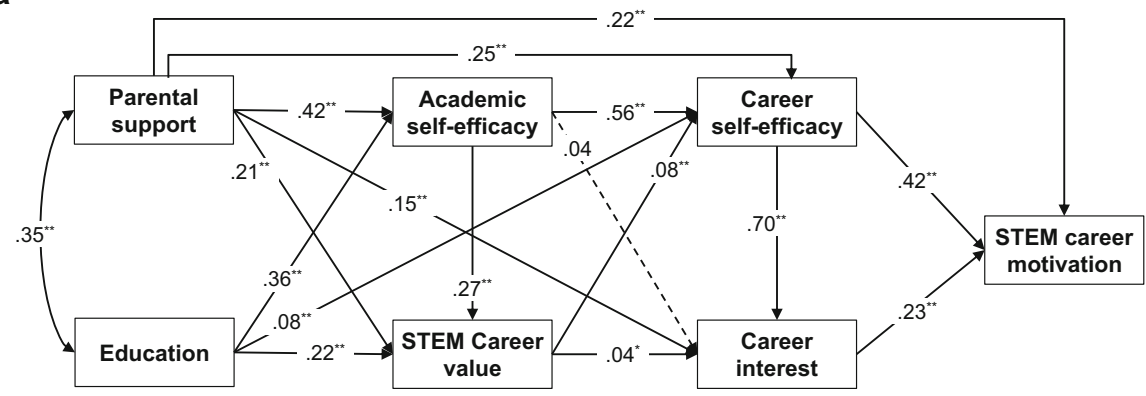

b

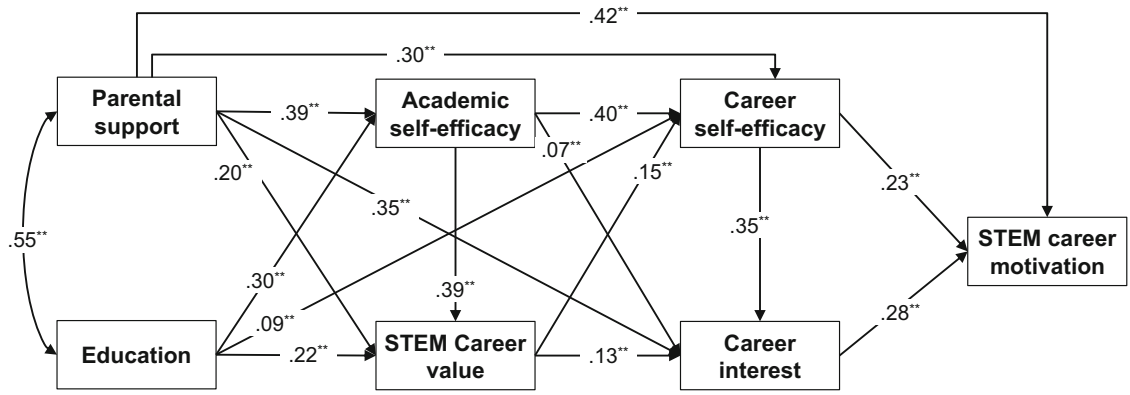

Figure 2 a Korean, b Indonesian

Table 6 Fit indices of path models

\begin{tabular}{lcccccc}
\hline & $\chi^{2}$ & df & \multicolumn{1}{c}{$p$} & CFI & RMSEA & SRMR \\
\hline Path model with full sample & 66.11 & 4 & $<.001$ & .993 & .084 & .016 \\
Multi-group analysis & & & & & & \\
Unconstraint & 49.36 & 8 & $<.001$ & .996 & .049 & .021 \\
Weight constraint & 269.13 & 24 & $<.001$ & .975 & .068 & .040 \\
Covariance constraint & 326.15 & 27 & $<.001$ & .969 & .071 & .053 \\
Residuals constraint & 515.29 & 32 & $<.001$ & .950 & .083 & .061 \\
\hline
\end{tabular}

\section{Discussion}

\section{Difference in STEM career motivation between Indonesian and Korean students}

The overarching purpose of this study was to understand secondary students' STEM career motivation by comparing Korean and Indonesian students. The effect of gender and educational level on STEM career motivation was also empirically examined. Findings indicated significant differences in all subcomponents of STEM career motivation between students from the two countries. There were also 
interaction effects between country-educational level and country-gender on STEM career motivation. These findings imply that STEM career motivation is affected by a combination of country, gender, and educational level in a complex way. Thus, when comparing STEM career motivation, both the country variable and its interaction effect with gender and educational level should be considered.

Our findings revealed significant interactions between country and educational level on STEM career motivation. For all STEM constructs, Indonesian high-school students scored higher than middle-school students, whereas Korean high-school students' STEM career motivation was much lower than that of middle-school students. In the last decade, the Korean government has implemented national policies, such as increasing entrance quotas in STEM majors and investing a large budget in order to meet STEM career demands. As a result, Korea has many STEM graduates, as mentioned in the introduction. However, paradoxically, it was found that Korean high-school students had much lower motivation for STEM careers than Indonesian students. The Korean policy for improving STEM fields appears to be effective in increasing STEM majors in college and manpower in the short term. However, the low level of career motivation implies that, even if many Korean students enter colleges with STEM majors, it is difficult to guarantee their retention in STEM fields in the long term.

Especially, given the findings that Korean high-school students have a lower STEM career motivation than middle-school students, it is assumed that the environment in Korea high-schools may not maintain motivation toward STEM. According to a previous study, many Korean high-school students are known to have difficulties in career development because of the psychological pressure of preparing for competitive university entrance exams and a lack of time for career development (Lee et al., 2013; Shin et al., 2017). Within such a competitive educational environment, the overall motivation for a STEM career may decline during the high-school years. Nevertheless, high school is an important period for career development, because students are exploring and choosing specific careers and majors in this period. In particular, it has been reported that many Korean scientists and engineers decided to pursue STEM fields when they were in high school (Lee, Park, Moon, Kim, \& Sohn, 2011). Thus, it is necessary to improve STEM career education to help students who are interested in STEM careers maintain motivation at this important period. Korea's STEM educators and policymakers should pay more attention to the development of students in general secondary schools, not just in the tertiary education system.

On the other hand, Indonesian students showed high levels of overall STEM career motivation and Indonesian high-school students scored higher on all STEM constructs than middle-school students. Their relatively high STEM career motivation means that Indonesian students think positively about STEM, and many Indonesian students' career development in STEM is already well underway. Indonesian students' high career motivation can be interpreted in two ways. First, students' positive attitudes toward science could be seen as a plausible reason. As mentioned previously, Indonesian students show high motivation for learning science in international assessments, such as PISA 2015 (OECD, 2016). Such a high motivation to learn science would lead to many students' positive motivation for a 
STEM career as well. Second, in the socio-economic context, Indonesia has been rapidly expanding and developing STEM fields in recent years. In Indonesia, STEM is considered to be a national growth driver. Thus, demand for experts in STEM fields is also increasing (World Bank, 2010). STEM fields in Indonesia are seen as a promising area, because there are not enough STEM experts yet compared to the rapidly increasing demand. This context could be an important background behind the high STEM career motivation in Indonesian students. High-school students with high STEM career motivation could become a STEM workforce and lead development in Indonesia. Therefore, the education system, especially the tertiary education system, in Indonesia should help sustain and develop these students' high motivation.

The interaction between country and gender was also significant for all constructs. While Korean students had a large discrepancy between genders, there was no such difference in Indonesia. Considering that Islam is the religion of more than $80 \%$ of the Indonesian population and that Indonesia is one of the largest Muslim countries, it is interesting that there are few gender differences in STEM career motivation among Indonesian students because Islamic societies typically show much gender inequality in several fields (Klingorovas \& Havlicek, 2015). However, the Indonesian government has been committed to gender equality. The fundamental ideology of Indonesia is derived from the diversity and equality of its citizens. The national motto of Indonesia is Bhinneka Tunggal Ika which means "unity in diversity" (Soh, 2007). To prevent things that might cause inharmonious circumstances, minorities are also considered equally in the life of Indonesians. For example, the Indonesian government has been working on "gender mainstream" policy for almost all government agencies and local governments. They have been promoting gender equality in education since 2000 (World Bank, 2006). These policy efforts might have led to Indonesian female students' high STEM career motivation.

There are also policies to foster female STEM careers in Korea, such as educational programs that encourage female students to enter STEM fields. However, our findings suggest that these policies seem to be far from meeting their goal of gender equality in STEM fields. There was a big gender gap in the level of STEM career motivation in Korea in this study. This finding is consistent with the results of previous studies showing that Korean female students do not aspire or intend to have a science career as much as male students do (Shin et al., 2017). At the same time, Korean female high-school students showed much less overall STEM career motivation than middle-school students. This result is similar to results of a previous study showing that female students feel less self-efficacy in science, and gender differences increase after the transition from middle school to high school (Pajares, 2005).

Given the fact that there were few gender gaps in either science or math achievement in several international assessments, such as PISA 2015, such a low level of Korean female students' motivation for a STEM career might be related to individual affective characteristics within the Korean socio-cultural context. One plausible reason is that there is a perception that a STEM field career will be more difficult for Korean women to balance with family life, because STEM fields are 
generally thought to be more masculine. In particular, the obligations of childbirth and child care have been reported to be a major reason for Korean female scientists' and engineers' intention to retire or consider retirement (Lee, Park, Sohn, \& Moon, 2012). Within these social contexts, it has been reported that career counseling for female students, parents, or teachers tends to emphasize the difficulties women face in STEM career paths or the fact that there are few women in STEM fields in Korea (UNESCO, 2015). These socio-cultural contexts might have led to Korean female students' significantly low level of STEM career motivation. They might also have interacted with individual psychological factors, such as a low self-concept or lack of interest in math and science. Large gender differences in STEM career motivation in Korean students would deepen the gender gap of STEM in Korea in the future, and be a stumbling block to the growth of Korean STEM fields with diverse and creative potential. Therefore, Korean STEM career education needs to develop a comprehensive STEM education policy to improve Korean female students' STEM career motivation. Especially, career educational strategies are needed to maintain female students' STEM career motivation during the transition from middle school to high school.

\section{Relationships between each construct of STEM career motivation}

To understand the relationships between constructs of STEM career motivation across different groups, we carried out correlation analysis and multiple group path analysis. The results of the correlation analysis revealed that each construct had a significant correlation with the others. These results imply that the constructs in STEM career motivation will more likely increase or decrease together rather than acting independently for most students. In particular, our finding showed that career self-efficacy and career interest had strong correlations with large effects for most groups. This result is consistent with the findings of previous research showing that self-efficacy plays a role in career development in Social cognitive career theory (SCCT) (Hackett \& Bryars, 1996). Thus, educational strategies that can improve students' self-efficacy about a STEM career could be effective for both Korean and Indonesian students' STEM career development.

However, although correlations between all subcomponents were significant, the size of Pearson correlation coefficients differed by country, gender, and educational level. This implies that the influence of each variable differs depending on the group. Considering differences in the relationships between constructs in each group, more effective STEM education can be achieved for each group. In addition, given our finding that Indonesian students showed a higher correlation between career goal setting and parental support, such support for a STEM career might have played a key role in Indonesian student's STEM career motivation. Therefore, STEM-related career programs for both parents and students might be effective for Indonesian STEM career development.

The results of multiple group path analysis revealed that Korean and Indonesian students' STEM career development process can be explained by SCCT. However, there was a significant difference in the pathway from academic self-efficacy to STEM career interest between Korean and Indonesian students. For Korean 
students, academic self-efficacy was not linked with career interest directly. In other words, although some Korean students have high self-efficacy in STEM-related subject, it is not easy for them to directly be interested in STEM as their future career. Instead, Korean students' academic self-efficacy indirectly connects with career interest through career self-efficacy as an important mediator. Therefore, to improve Korean students' STEM career motivation, promoting not only their academic self-efficacy in STEM but also their career self-efficacy is required. According to Bandura (1977), one source of self-efficacy is vicarious experience, which refers to observing others who are similar to them perform a task successfully. In this regard, it might be effective for improving Korean students' career motivation to have educational programs such as meeting professionals in real STEM fields who have backgrounds similar to those of students.

\section{Limitations and future direction}

This study has several limitations. First, it focused on educational experience and parental support as contextual factors that constituted motivation for a STEM career. Data on these contextual factors were collected by measuring student's perceived parental support and perceived educational experience. However, we could not exclude the possibility that students' perceived experience and support might differ from real experience in activities related to STEM career education or from teacher and parents' perception of their students' or children's decisions on a STEM career. Thus, further study of these contextual factors is needed to understand the contextual aspect of STEM career motivation comprehensively.

Second, in this study, we examined career motivation in overall STEM fields, not each specific field, such as biology and engineering. However, STEM fields include various subfields and students' career motivation may differ for each field. In particular, it is generally known that female students prefer the biomedical field more than male students (Diekman et al., 2011). There may be meaningful differences in preferred fields depending on the socio-cultural context of each country.

Third, this study was conducted with a descriptive cross-sectional approach. It examined how different students' STEM career motivation varied across country, gender, and educational level but did not examine causes of these differences. Instead we discussed plausible reasons based on socio-cognitive context and previous research. Further empirical studies that explore socio-cognitive variables such as social economic status, gender inequality index, academic stress index or qualitative data through in-depth interview could better explain the causes of differences in students' STEM career motivation. Moreover, to understand students' career development in STEM, consideration of changes over time is also required. STEM career development can be understood more clearly if the STEM career motivation of students is examined by a longitudinal approach. 


\section{Conclusion}

Educating a high-quality STEM workforce over the long-term requires considering individual career development. In this study, we assumed that STEM career motivation was one important indicator of students' career development in STEM. We attempted to provide global insights for STEM education by comparing STEM career motivation between Korean and Indonesian secondary students. Our results indicated that STEM career motivation had different patterns in the two countries. Students' motivation toward STEM was affected by a combination of country, educational level, and gender in a complex way. These results underscore the need to consider socio-cultural contexts embedded in each country related to gender and educational level when examining secondary students' STEM career motivation.

In recent years, international academic exchanges and scholarly cooperation have been actively carried out to develop STEM and solve the problem of a deficient STEM workforce in various fields including STEM education. In the process of international exchange, motivational characteristics of students from different countries and their social contexts need to be considered to produce more efficient results. Difference in relationships between career motivational constructs by the country need to be considered as well. Our findings suggest that Korean STEM career education needs to be developed to improve high-school students' career motivation. An improved educational strategy for female high-school students is especially required. For Indonesia, investing in STEM education at universities might be more effective in increasing the STEM workforce so that the relatively high STEM career motivation in high-school students can be maintained.

Open Access This article is distributed under the terms of the Creative Commons Attribution 4.0 International License (http://creativecommons.org/licenses/by/4.0/), which permits unrestricted use, distribution, and reproduction in any medium, provided you give appropriate credit to the original author(s) and the source, provide a link to the Creative Commons license, and indicate if changes were made.

\section{References}

Bandura, A. (1977). Self-efficacy: Toward a unifying theory of behavioral change. Psychological Review, 84(2), 191-215. https://doi.org/10.1037/0033-295X.84.2.191.

Barmby, P., Kind, P. M., \& Jones, K. (2008). Examination changing attitudes in secondary school science. International Journal of Science Education, 30(8), 1075-1093. https://doi.org/10.1080/ 09500690701344966.

Bell, R. C. (1982). Person fit and person reliability. Educational Research and Perspectives, 9(1), 105-113. Retrieved from https://www.rasch.org/erp8.htm.

Bond, T., \& Fox, C. M. (2015). Applying the Rasch model: Fundamental measurement in the human sciences. New York: Routledge.

Boone, W. J., \& Scantlebury, K. (2006). The role of Rasch analysis when conducting science education research utilizing multiple choice tests. Science Education, 90(2), 253-269. https://doi.org/10.1002/ sce. 20106.

Boone, W. J., Staver, J. R., \& Yale, M. S. (2014). Rasch analysis in the human sciences. Dordrecht: Springer. https://doi.org/10.1007/978-94-007-6857-4.

Chen, D. (2009). Vocational schooling, labor market outcomes, and college entry. Policy research working paper 4814. Washington, DC: World Bank. 
Cheung, G. W., \& Rensvold, R. B. (2002). Evaluating goodness-of-fit indexes for testing measurement invariance. Structural Equation Modeling, 9, 233-255.

Chiu, M. H., \& Duit, R. (2011). Globalization: Science education from an international perspective. Journal of Research in Science Teaching, 48(6), 553-566. https://doi.org/10.1002/tea.20427.

Cohen, J. (1969). Statistical power analysis for the behavioural sciences. New York: Academic Press. https://doi.org/10.1016/B978-0-12-179060-8.50012-8.

Crane, P. K., Cetin, K., Cook, K. F., Johnson, K., Deyo, R., \& Amtmann, D. (2007). Differential item functioning impact in a modified version of the Roland-Morris disability questionnaire. Quality of Life Research, 16(6), 981-990. https://doi.org/10.1007/s11136-007-9200-x.

DeVellis, R. F. (2003). Scale development: Theory and applications (2nd ed.). Thousand Oaks, CA: Sage.

Diekman, A. B., Clark, E. K., Johnston, A. M., Brown, E. R., \& Steinberg, M. (2011). Malleability in communal goals and beliefs influences attraction to STEM careers: Evidence for a goal congruity perspective. Journal of Personality and Social Psychology, 101(5), 902-918. https://doi.org/10. 1037/a0025199.

Fantom, N., \& Serajuddin, U. (2016). The World Bank's classification of countries by income, policy research working paper 7528. Washington DC: World Bank. Retrieved from http://documents. worldbank.org/curated/en/408581467988942234/pdf/WPS7528.pdf.

Fouad, N. A., Kantamneni, N., Smothers, M. K., Chen, Y. L., Fitzpatrick, M., \& Terry, S. (2008). Asian American career development: A qualitative analysis. Jornal of Vocational Behavior, 72(1), 43-59. https://doi.org/10.1016/j.jvb.2007.10.002.

Good, C., Aronson, J., \& Harder, J. A. (2007). Problems in the pipeline: Stereotype threat and women's achievement in high-level math courses. Journal of Applied Developmental Psychology, 29(1), 17-28. https://doi.org/10.1016/j.appdev.2007.10.004.

Hackett, G., \& Betz, N. E. (1989). An exploration of the mathematics of self-efficacy/mathematics performance correspondence. Journal for Research in Mathematics Education, 20(3), 261-273. https://doi.org/10.2307/749515.

Hackett, G., \& Bryars, A. M. (1996). Social cognitive theory and the career development of African American women. Career Development Quarterly, 44, 322-340. https://doi.org/10.1002/j.21610045.1996.tb00449.x.

Halpern, D. F., Bendow, C. P., Geary, D. C., Gur, R. C., Hyde, J. S., \& Gernsbacher, M. A. (2007). The science of sex differences in science and mathematics. Psychological Science in the Public Interest, 8(1), 1-51. https://doi.org/10.1111/j.1529-1006.2007.00032.x.

Hamilton, A. F., Malin, J., \& Hackmann, D. (2015). Racial/ethnic and gender equity patterns in Illinois high school career and technical education coursework. Journal of Career and Technical Education, 30(1), 29-52. https://doi.org/10.21061/jcte.v30i1.712.

Holland, J. L. (1997). Making vocational choices: A theory of vocational personalities and work environments (3rd ed.). Odessa, FL: Psychological Assessment Resources.

Jon, J. E., \& Chung, H. I. (2013). Consultant Report Securing Australia's Future STEM: Country Comparisons. STEM Report-Republic of Korea. Retrieved from https://www.acola.org.au/PDF/ SAF02Consultants/Consultant\%20Report\%20-\%20Korea.pdf.

JPPN. (2015, October 7). Jumlah Siswa SMK Kalahkan SMA, Ini Datanya. Retrieved May 03, 2017, from http://www.jpnn.com/news/jumlah-siswa-smk-kalahkan-sma-ini-datanya.

Keith, T. Z. (1993). Causal influences on school learning. In H. J. Walberg (Ed.), Analytic methods for educational productivity (pp. 21-47). Greenwich, CT: JAI Press.

Klingorova, K., \& Havlicek, T. (2015). Religion and gender inequality: The status of women in the societies of world religions. Moravian Geographical Reports, 23(2), 2-11. https://doi.org/10.1515/ mgr-2015-0006.

Koo, H. (2000). The dilemmas of empowered labor in Korea: Korean workers in the face of global capitalism. Asian Survey, 40(2), 227-250. https://doi.org/10.2307/3021131.

Lee, H., Park, Y., Moon, M., Kim, J., \& Sohn, J. (2011). Performances and future prospect of policies for the support and cultivation of women scientists and engineers. A policy research report submitted to MEST. Seoul: Center for Women In Science, Engineering, and Technology.

Lee, I. H., Rojewski, J. W., \& Hill, R. B. (2013). Classifying Korean adolescents' career preparedness. International Journal for Educational and Vocational Guidance, 13(1), 25-45. https://doi.org/10. 1007/s10775-012-9236-5.

Lee, H., Park, Y. Sohn, J., \& Moon, M. (2012). An exploratory study on intention to quit among highlyeducated women scientists \& engineers. The Women's Studies, 83(2), 35-69. Retrieved from: http:// 
www.kwdi.re.kr/researchWomenList.kw?sgrp=S01\&siteCmsCd=CM0001\&topCmsCd=CM0002\& cmsCd=CM0009\&pnum=7\&cnum=1\&volumeSel=\%EC\%A0\%9C83\%ED\%98\%B8.

Lent, R. W., Brown, S. D., \& Hackett, G. (1994). Toward a unifying social cognitive theory of career and academic interest, choice and performance. Journal of Vocational Behavior, 45(1), 79-122. https:// doi.org/10.1006/jvbe.1994.1027.

Lent, R. W., Brown, S. D., \& Hackett, G. (2000). Contextual supports and barriers to career choice: A social cognitive analysis. Journal of Counseling Psychology, 47(1), 36-49. https://doi.org/10.1037/ 0022-0167.47.1.36.

Leong, F. T. L. (1993). The career counseling process with racial-ethnic minorities: The case of Asian Americans. The Career Development Quarterly, 42, 26-40. https://doi.org/10.1002/j.2161-0045. 1993.tb00242.x.

Liou, P. Y. (2014). Examining the big-fish-little-pond effect on students' self-concept of learning science in taiwan based on the TIMSS databases. International Journal of Science Education, 36(12), 2009-2028. https://doi.org/10.1080/09500693.2014.889331.

Lofgran, B. B., Smith, L. K., \& Whiting, E. F. (2015). Science self-efficacy and school transitions: Elementary school to middle school, middle school to high school. School Science and Mathematics, 115(7), 366-376. https://doi.org/10.1111/ssm.12139.

Marginson, S., Tytler, R., Freeman, B., \& Roberts, K. (2013). STEM: country comparisons: international comparisons of science, technology, engineering and mathematics (STEM) education. Final report. Australian Council of Learned Academies, Melbourne, Victoria. Retrieved from: http://dro.deakin. edu.au/view/DU:30059041.

Marsh, H. W., Seaton, M., Trautwein, U., Lüdtke, O., Hau, K. T., O’Mara, A. J., \& Craven, R. G. (2008). The big-fish-little-pond-effect stands up to critical scrutiny: Implications for theory, methodology, and future research. Educational Psychology Review, 20(3), 319-350. https://doi.org/10.1007/ s10648-008-9075-6.

Marton, F., Watkins, D., \& Tang, C. (1997). Discontinuities and continuities in the experience of learning: An interview study of high-school students in Hong Kong. Learning and Instruction, 7(1), 21-48. https://doi.org/10.1016/S0959-4752(96)00009-6.

Mau, W. C. J. (2016). Characteristics of US students that pursued a STEM major and factors that predicted their persistence in degree completion. Universal Journal of Educational Research, 4(6), 1495-1500. https://doi.org/10.13189/ujer.2016.040630.

Meece, J. L., Glienke, B. B., \& Burg, S. (2006). Gender and motivation. Journal of School Psychology, 44(5), 351-373. https://doi.org/10.1016/j.jsp.2006.04.004.

Mendikbud [Indonesian Ministry of Education and Culture]. (2016). Salinan Lampiran Permendikbud No.21 th 2016 tentang Standar Isi Pendidikan Dasar dan Menengah [A copy of the additional documents of Indonesian ministry of education and culture regulation number 21 year 2016 on Content Standards for Primary and Secondary Education].

Messick, S. (1995). Standards of validity and the validity of standards in performance assessment. Educational Measurement: Issues and Practice, 14(4), 5-8. https://doi.org/10.1111/j.1745-3992. 1995.tb00881.x.

Ministry of National Education. (2006). Rencana Strategis Departemen Pendidikan National Tahun 2005-2009. Jakarta: Ministry of National Education.

Misbah, Z., Gulikers, J., Maulana, R., \& Mulder, M. (2015). Teacher interpersonal behaviour and student motivation in competence-based vocational education: Evidence from Indonesia. Teaching and Teacher Education, 50, 79-89. https://doi.org/10.1016/j.tate.2015.04.007.

Mukaka, M. (2012). A guide to appropriate use of correlation coefficient in medical research. Malawi Medical Journal: The Journal of Medical Association of Malawi, 24(3), 69-71. Retrieved from: https://www.ncbi.nlm.nih.gov/pmc/articles/PMC3576830/.

Mullis, I. V. S., Martin, M. O., Foy, P., \& Hooper, M. (2016). TIMSS 2015 international results in science. Chestnut Hill, MA: TIMSS \& PIRLS International Study Center, Boston College.

Newhouse, D., \& Suryadarma, D. (2011). The value of vocational education: High school type and labor market outcomes in Indonesia. The World Bank Economic Review, 25(2), 296-322. https://doi.org/ 10.1093/wber/lhr010.

Nugent, G., Barker, B., Welch, G., Grandgenett, N., Wu, C., \& Nelosn, C. (2015). A model of factors contributing to STEM learning and career orientation. International Journal of Science Education, 37(7), 1067-1088. https://doi.org/10.1080/09500693.2015.1017863.

OECD. (2015). OECD Science, technology and industry scoreboard 2015: Innovation for growth and society. Paris: OECD Publishing. 
OECD. (2016). PISA 2015 results: Excellence and equity in education, PISA (Vol. I). Paris: OECD Publishing.

Oh, Y. J., Jia, Y., Lorentson, M., \& LaBanca, F. (2013). Development of the educational and career interest scale in science, technology, and mathematics for high school students. Journal of Science Education and Technology, 22, 780-790. https://doi.org/10.1007/s10956-012-9430-8.

Pajares, F. (2005). Gender differences in mathematics self-efficacy beliefs. In A. M. Gallagher \& J. C. Kaufman (Eds.), Gender differences in mathematics: An integrative psychological approach (pp. 294-315). Boston: Cambridge University Press.

Palmer, R. T., Maramba, D. C., \& Dancy, T. E. (2011). A qualitative investigation of factors promoting the retention and persistence of students of color in STEM. The Journal of Negro Education, 80(4), 491-504. Retrieved from www.jstor.org/stable/41341155.

Renninger, K. A., \& Su, S. (2012). Interest and its development. In R. M. Ryan (Ed.), The Oxford Handook of human motivation (pp. 167-187). Oxford, NY: Oxford University Press. https://doi.org/ 10.1093/oxfordhb/9780195399820.001.0001.

Riegle-Crumb, C., Moore, C., \& Ramos-Wada, A. (2011). Who wants to have a career in science or math? Exploring adolescents' future aspirations by gender and race/ethnicity. Science Education, 95(3), 458-476. https://doi.org/10.1002/sce.20431.

Schneider, B., Judy, J., \& Mazuca, C. (2012). Boosting STEM interest in high school. Phi Delta Kappan, 94(1), 62-65. https://doi.org/10.1177/003172171209400112.

Schunk, D. H., \& Usher, E. L. (2012). Social cognitive theory and motivation. In R. M. Ryan (Ed.), The Oxford handbook of human motivation (pp. 13-27). Oxford, NY: Oxford University Press. https:// doi.org/10.1093/oxfordhb/9780195399820.001.0001.

Shin, S., Ha, M., \& Lee, J. K. (2016). The development and validation of instrument for measuring high school students' STEM career motivation. Journal of the Korean Association for Science Education, 37(1), 75-86. https://doi.org/10.14697/jkase.2016.36.1.0075.

Shin, S., Ha, M., \& Lee, J. K. (2017). Influence of career motivation on science learning in Korean highschool students. EURASIA Journal of Mathematics Science and Technology Education, 13(5), 1517-1538. https://doi.org/10.12973/eurasia.2017.00683a.

Simpkins, S. D., Davis-Kean, P. E., \& Eccles, J. S. (2006). Math and science motivation: A longitudinal examination of the links between choices and beliefs. Developmental Psychology, 42(1), 70-83. https://doi.org/10.1037/0012-1649.42.1.70.

Soh, B. (2007). In search of "Unity in Diversity": The image of women in new order Indonesia. International Area Review, 10(2), 67-94. https://doi.org/10.1177/223386590701000205.

Sorge, C. (2007). What happens? Relationship of age and gender with science attitudes from elementary to middle school, Science Educator, 16(2), 33-37. Retrieved from: http://files.eric.ed.gov/fulltext/ EJ783419.pdf.

Super, D. E. (1980). A life-span, life-space approach to career development. Journal of Vocational Behavior, 16(3), 262-298. https://doi.org/10.1016/0001-8791(80)90056-1.

UNESCO. (2015). A complex formula: Girls and women in science, technology, engineering and mathematics in Asia. New York: UNESCO. UNESCO Bangkok Office.

Wang, X. (2013). Why students choose STEM majors: Motivation, high school learning, and postsecondary context of support. American Educational Research Journal, 50(5), 1081-1121. https://doi.org/10.3102/0002831213488622.

Wang, M. T., \& Degol, J. L. (2017). Gender gap in Science, Technology, Engineering and Mathematics (STEM): Current knowledge, implication for practice, policy, and future directions. Educational Psychology Review, 29(1), 119-140. https://doi.org/10.1007/s10648-015-9355-x.

World Bank. (2006). Indonesia-Country gender assessment. Washington, DC: World Bank.

World Bank. (2010). Indonesia skills report: Trends in skills demand, gaps, and supply in Indonesia. Report No. 54741-EAP.

Wright, B. D., Linacre, J. M., Gustafson, J. E., \& Martin-Löf, P. (1994) Reasonable mean-square fit values. Rasch Measurement Transactions, 8(3), 370. Retrieved from https://www.rasch.org/rmt/ rmt83b.htm. 